\title{
Developing an Integrative Theoretical Framework for Climate Proofing Spatial Planning Across Sectors, Policy Levels and Planning Areas
}

\author{
Maria Juschten 1, Florian Reinwald 2, Roswitha Weichselbaumer ${ }^{2}$, Alexandra Jiricka-Pürrer 1,* \\ 1 Institute of Landscape Development, Recreation and Conservation Planning, University of Natural Re- \\ sources and Life Sciences, Vienna; maria.juschten@boku.ac.at / alexandra.jiricka@boku.ac.at \\ 2 Institute of Landscape Planning, University of Natural Resources and Life Sciences, Vienna; florian.rein- \\ wald@boku.ac.at / roswitha.weichselbaumer@boku.ac.at \\ * Correspondence: alexandra.jiricka@boku.ac.at; Tel.: +43 1- 47654-85323
}

\begin{abstract}
Spatial planning holds a key role in preventing or mitigating the impacts of climate change on both cities and rural areas, taking a forward-thinking and holistic approach to urban and regional development. As such, spatial planning deals with challenges occurring at different scales and across sectors. The international literature points out the need for horizontal and vertical cooperation to tackle climate change impacts. While there is abundant knowledge regarding the challenges related to climate change at different spatial levels, procedural integration into planning frameworks and practice is currently under-researched. This paper presents a novel theoretical framework that integrates various steps towards a holistic, integrative and adaptive climate proofing process. An iterative process was used for conceptual development, based on literature review followed by external feedback meetings and two workshops with the core team of planning experts responsible for exchange across federal states. By specifically addressing the challenges relating to crossregional and cross-sectoral planning, this novel framework attempts to (i) facilitate a hierarchy of measures, (ii) maximise co-benefits for various adaptation purposes and climate change mitigation and (iii) foster the long-term institutionalisation of integrative processes across sectors, planning areas and policy levels.
\end{abstract}

Keywords: climate proofing; spatial planning; climate change adaptation; framework; cross-regional; integral; co-benefits

\section{Introduction}

Climate change can bring about a change in the frequency and intensity of meteorological phenomena. These changes give rise to different thematic challenges which depend on geographical location, topographical and climatic conditions, as well as other influencing factors such as land use. While, in coastal areas, for example, protection against storm surges is the main concern [1-3], other areas primarily suffer from heatwaves and droughts, causing forest fires and/or water scarcity [4-6]. Alpine areas, on the other hand, have specific challenges primarily related to gravitational events such as erosion, landslide and rockfall. Their intensity also depends on other factors such as soil characteristics and the location of settlements [7]. Extreme events in particular can have a severe impact on settlement areas and their populations, transport infrastructure, energy supply and other sectors [8-10]. Of particular relevance in this context is the impact on critical infrastructure such as power supply or transport links for places of major public significance or with important health or safety functions (e.g. hospitals). The interconnectedness of different critical infrastructures and interactions between them exacerbate this problem [11,12]. 
Spatial planning can contribute significantly to the prevention or mitigation of climate-related risks or damages, both through spatial research and the support of planning decisions [13]. Spatial planning decisions can determine developments for years or even decades. Land usage patterns and building developments are not only influenced by potential climate change impacts; they also hold the key of adapting to them. This is why forward-thinking planning practices have become the focus of spatial planning research in the last two decades. Such practices include, among other things, the increase of spatially-specific climate and adaptation knowledge, the development of scenarios for adaptation to climate change, the strategic promotion of nature-based solutions, and the monitoring of them [14].

In addition to strategic development, liability issues and financial risks have also become increasingly relevant. This is especially true at municipal level, as planning decisions can have far-reaching consequences, depending on the longevity of the infrastructure following planning decisions or the impact on territorial systems. In this context, the possibility of adaptation, with the goal of preventing and/or reducing damages and business interruptions, has also become part of international research and planning practice. Numerous studies have addressed issues related to vulnerability or risk reduction in the context of spatial development [2,15-17].

Kruse \& Pütz [18] emphasise the intrinsic long-term focus of planning processes that may be based on the precautionary principle [19]. In doing so, planners and policymakers try to avoid negative path dependencies while at the same time creating positive ones. Two aspects are important in this context: firstly, the proactive management of spaces, for instance through the preservation or expansion of green spaces or the designation of specific adaptation-relevant areas, and secondly, the identification of new risks that arise through the implementation of a plan/programme [20,21]. Over the decades, planning processes have paid much attention to some aspects of climate change, such as the risk of flooding $[2,22]$. However, awareness of and attention in the planning process to other aspects, such as the effects of heat and drought and response to them, have only grown recently.

In response to these different climatic changes, planners and decision-makers try to find long-term measures to reduce negative impacts, often referred to as "climate proofing". Swart et al. [2] define "climate proofing", in the context of spatial planning, as initiatives of different administrative or sectoral authorities aiming to "integrate climate impacts concerns in land use, water management and other projects in order to make a location, a region, a district or an economic sector resilient to climate change (...)", thereby reducing its vulnerability. This is to ensure that plans, programmes and strategies, as well as associated investments, are resilient and adaptable both to the current and future impacts of climate change [23]. Given this definition, resilience, as the ability of urban/regional systems to adapt to external influences and to mitigate negative impacts, plays a central role in many climate proofing frameworks [see for example 12,24,25]. A systems-based approach to climate proofing would aim at increasing robustness and resilience. This would have the major advantage of maintaining the flexibility and agility of the planning instruments, allowing planners to adjust proactively to changing circumstances.

International science and governing institutions have been analysing opportunities for strengthening resilience to climate change in spatial planning for around twenty years now [2]. As part of this process, guiding concepts and frameworks have been developed to integrate climate proofing objectives at an early stage of the planning process and in a forward-looking manner. Within existing international studies and guidance documents, two particular challenges of spatial planning have only been addressed partially so far. One challenge refers to the importance of tiering between different spatial levels, which requires early consideration of planning alternatives in order to be able to specifically and appropriately implement further climate proofing measures at subsequent spatial levels. Another challenge relates to the difficulty of taking into account any changes in climatic conditions beyond the scope of the given planning areas [26]. 
In particular, the avoidance of "lock-in effects" $[27,28]$, the lack of institutional flexibility in adapting policies to changing circumstances $[3,29,30]$ as well as responses to increasing resource scarcities [29,31] are described as major challenges in both the international literature as well as in strategy documents and adaptation policies also in this context. These challenges can be addressed, among other options, by finding solutions that transcend spatial, policy level and administrative boundaries. Several international studies highlight the importance of both integral and cross-regional climate proofing processes for diverse spatial conditions [11,19,26,32].

Next to the consideration of climate change along horizontal and vertical planning boundaries, the integration of sources of information and planning objectives from instruments of sectors complementary to spatial planning, are highlighted by some studies. Kruse und Pütz [18], for instance, emphasised the importance of spatial planning for adaptation to climate change, especially with regard to sectoral dependencies (e.g. between water and soil).

This article, based on a large case study in the eastern part of Austria involving three different federal states - each with its own legal planning law and instruments - discusses a framework for an integrative systematic approach, across planning borders, to the complex challenges of climate proofing. In doing so, this communication addresses the following research question: how can a theoretical framework integrate the opportunities of climate proofing across sectors, policy levels and planning areas?

Below we will discuss this new framework concept which i) integrates climate change impacts into spatial planning across planning levels and planning areas, including the longer-term reintegration of review steps at the different levels, and which also ii) provides for the integral consideration of cross-sectoral approaches to climate proofing in different sub-steps.

\section{Methodological Approach}

\subsection{Description of the Case Study}

The case study for this project and the resulting framework development is Eastern Austria, which is a very heterogeneous planning area that will be affected by a variety of meteorological and resulting planning challenges as climate change progresses. Three federal states-Vienna, Lower Austria and Burgenland-founded "Planungsgemeinschaft OST" (PGO), a joint organisation for the harmonisation, coordination and preparation of questions relevant to spatial planning in the eastern region.

The area is characterised by strong contrasts. It includes a metropolitan region, as is Vienna with its population of nearly two million and is therefore characterised by the cross-sectoral pressure of land use change in the vicinity of Vienna. It also includes numerous small communities in remote areas with structural difficulties and limited resources available for their adaptation to climate change. Another central challenge is that planning law in Austria is a matter for the federal states, i.e. all three federal states have different planning laws. The planning instruments and the administrative structures also differ.

\subsection{Multi-Method Approach to the Development of the Framework}

The project chose a multi-level methodological approach. It is based on the review of the current state of scientific knowledge, the indicative requirements of strategies and policies, as well as existing guidelines for national and international planning practice.

Coordination on the framework structure took place in several oral and written feedback loops with the core team of planning experts responsible for the exchange across federal states. Their feedback was obtained through multiple discussion sessions as well as a workshop with an extended group of experts from the planning field in mid-October 2020 and March 2021. 


\section{Background - Specific Challenges for Climate Proofing in Spatial Planning}

\subsection{Challenges for Climate Proofing in Spatial Planning Across Planning Levels and Areas} (Scopes)

In many countries, the mainstreaming of climate proofing is based on National Adaptation Strategies, which identify impacts of climate change on a rather abstract scale and superior levels and introduce measures also for spatial planning and related sectors [32]. To implement these measures and redefine specific needs against the background of the specific spatial situation, downscaling and concretisation are necessary. Consideration of over-arching challenges can support these processes at regional and local level. For planning practice, some frameworks exist that aim to support the process of implementing climate proofing measures at different policy levels. While they often include processes of stakeholder involvement or cooperation with relevant sectoral or political stakeholders, they tend to focus on very specific regional scales. The most frequently studied level of analysis is the urban level, where a wide range of planning or implementation frameworks is designed for [see for example 33-35]). This imbalance may be attributed to data availability but also to the high sensitivity of urban areas to climate change, given their often increased exposure to the projected impacts of climate change (i.e. coastal locations or heat islands) as well as the large and often increasing size of the population affected [36,37].

While the literature pays some attention to such vertical levels of cooperation across different policy scales (national to regional to local, also framed as "mainstreaming") [38$40]$, little consideration is given to horizontal levels of cooperation, including the challenges of cross-regional or transboundary cooperation. This entails cooperation across different regions at the same administrative or hierarchical level [32,39]. Especially for the challenges of cross-regional planning within countries, linkages for their consideration would need to be created, again at different planning levels. So far, however, the procedural integration of cross-regional challenges has only been addressed within individual, often isolated and project-based case studies on the implementation of climate change adaptation processes [41,42]. Many of them operate at the urban level while integrating surrounding regions or federal states [for example in the case of the joint river management of Berlin with the surrounding region Brandenburg, see 26,or in the case of adaptation of road infrastructure in the metropolitain region of Stuttgart, see 43]). International research on the matter, however, is currently scarce [see 44 for a noteworthy exception].

Van Eerd et al. [45] highlight the importance of this horizontal or cross-border cooperation by stating that "Climate adaptation is inherently transboundary in character, as climate change effects do not stop at man-made borders". This applies particularly to the effects of heat and drought as well as the ability to respond to them, which require consideration beyond singular planning structures such as one community and its planning boundaries [45]. Similarly, flooding and the response to it necessitate broader consideration as rivers and brooks involve large areas, influenced by the combination of land uses [26]. While van Eerd et al. [45], among others [see for example 46], use this argument to justify the need for cooperation across national borders, the same argument can be used for cooperation across regional borders or planning areas, as emphasised by two publications on several geographical contexts in Europe, the US and Australia $[19,47]$. Both negative effects as well as potential co-benefits are transboundary in nature, given their dynamic movement $[45,48]$. The UN Water Policy brief [48], among others, emphasises the importance of integrating transboundary cooperation at all stages of the climate proofing process, therefore affecting a range of different steps or aspects. While research has clearly stated the need for more integrated, cross-border planning practices [26], such processes also come with a number of challenges that ought to be addressed or at least considered by planning institutions.

Several suggestions as to how to overcome these challenges are made by international studies. Persson [49] distinguishes between three different approaches with regard 
to measures that aim to increase the integration of environmental policies at different levels and enhance more integrative perspectives. One possible (normative) approach refers to reforms or administrative restructuring processes in order to change the rules underlying existing cooperation processes. Another (organisational) approach focuses on administrative structures within the appropriate planning bodies and possible measures which entail the re-allocation or new establishment of financial resources, staff, data access or other resources crucially needed for enhanced cooperation. A last (procedural) approach focuses on processes of cooperation between different planning bodies, including new processes of joint decision making and information exchange between planning bodies. Ideally, such processes targeted at increased cooperation would be established long term. However, they often tend to be only voluntary or temporary [31]. Widmer [32] specifies that measures targeted towards the different approaches can entail varying levels or intensities of cooperation. They range from mere coordination of processes (low coordination), to harmonisation and prioritisation (highest level of cooperation).

To sum up, the literature reveals that, to date, a number of frameworks exist that outline essential climate proofing sub-steps [see for example 50,51], often applied within specific planning areas (i.e. urban or regional contexts). However, the challenges related to spatial planning across policy levels and planning areas have not yet been explicitly integrated into the procedural approaches to climate proofing.

\subsection{Integral Spatial Planning to Enhance Climate Proofing}

At policy and strategy level, several authors stress the need for cross-sectoral adaptation [32,40,44,52]. Widmer [32] highlights the importance of addressing the "crosscutting nature of adaptation" within planning processes, even though her work focusses on planning processes across different policy sectors rather than administrative boundaries. Similarly but with a sectoral focus on water management, Haaren \& Moss [47] emphasise the need for more integrative planning across sectors, planning areas and policy levels, which they attribute to the complexity of current challenges (i.e. climate change, technological and demographic changes) as well as the scarcity of public financial resources attributed to these tasks.

In this context particularly, conflicting interests, e.g. due to the aggravating scarcity of resources, were highlighted [32], but also the ability to create positive synergies or cobenefits between multiple adaptation and even mitigation goals. In their analysis of 100 adaptation projects in the Netherlands, Swart et al. [2] provide examples of the possible co-benefits of climate adaptation with other sectoral goals from housing, transportation and recreation among others.

At local and regional level, several challenges were identified, which often relate to sector-specific instruments and administrative boundaries across sectors as well. Next to institutional and process-related constraints, data and the ability to include projections for various land uses are often mentioned as challenging. Harrison et al. [53], for instance, state that climate models often disregard interactions between different sectors with regard to short and long-term effects, which eventually may lead to misinterpretation of results [see also 54]. Particularly, resource consumption and competing interests e.g. regarding water usage for various adaptation purposes, can often not be considered transparently across planning boundaries and involving all relevant sectors accessing and impacting these resources.

While some initial research projects pointed out the limitations of spatial planning instruments in adapting to some impacts of climate change, others opted for a more integrative role for spatial planning in connecting necessary data, actors and processes, to enable cross-sectoral climate change adaptation. One noteworthy example includes the study by Floater et al. [35], who developed a framework for assessing the possible cobenefits of climate proofing measures that extend to other sectors and may therefore increase support from and cooperation with other administrative bodies affected. In this respect, the City of Rotterdam and its 'Climate Initiative' highlight the importance of en- 
suring cooperation and commitment from a range of different public and private stakeholders, although their perspective on cooperation only extends over various sectoral boundaries, but not its city boundaries [55]. A similar line of argument is followed by Kim and Lim [56], who highlight the relevance of interactions between sectors within their urban resilience framework, however focusing on sectors within city boundaries. While urban and suburban structures are more frequently and systematically assessed in crosssectoral cooperation with regard to climate change impacts and their capacity to react to climate change, rural areas partly neglect the full potential of coping with climate change by means of integral planning across sector-specific instruments. However, positive examples exist, especially with regard to adaptation efforts to prevent flooding along riversides, where diverse cooperation between water management and spatial planning is often institutionalised for decades [see 2 for a list of projects and their geographical and sectoral focus].

\subsection{Challenges of Climate Proofing Processes Across Sectors, Policy Levels and Planning Areas}

The previous sections discussed the importance but also the challenges of developing an integrative framework of climate proofing that fosters both vertical and horizontal cooperation by integrating stakeholders from different sectors, planning areas and policy levels. Above all, such an approach to spatial planning allows planners to respond more effectively, rationally and transparently to changing circumstances (i.e. technological, demographic, climatic changes) that affect land use and well-being across different sectors and planning areas $[26,57]$. For spatial planning, these aspects are highly relevant when discussing the benefits of involving a diverse set of other sectors such as water management, forestry or geology during the preparation of new plans and programmes as well as during the decision-making process. In order to develop a framework responsive to the specific challenges resulting from this integrative approach, a systematic review of the opportunities and challenges of integrative cooperation to achieve climate proofing targets is needed. Table 1 below provides this by subsuming existing literature [26,57]. 
Table 1. Opportunities and challenges of integrative cooperation in climate proofing

\begin{tabular}{|c|c|c|}
\hline Categories & $\begin{array}{c}\text { Opportunities of } \\
\text { Integrative Spatial Planning }\end{array}$ & $\begin{array}{c}\text { Challenges of } \\
\text { Integrative Spatial Planning }\end{array}$ \\
\hline $\begin{array}{c}\text { Institutionalisation } \\
\text { of } \mathbf{C P}\end{array}$ & $\begin{array}{l}\text { More strategic, long-term co- } \\
\text { ordination and increased level } \\
\text { of harmonisation of processes } \\
\text { and legal frameworks to } \\
\text { avoid maladaptation [57] }\end{array}$ & $\begin{array}{c}\text { Most current cooperation pro- } \\
\text { cesses across planning areas are } \\
\text { short-term/project-based, driven } \\
\text { by individuals and not institution- } \\
\text { alised }[32,36]\end{array}$ \\
\hline $\begin{array}{c}\text { Data/ } \\
\text { Know-How }\end{array}$ & $\begin{array}{l}\text { Data and knowledge ex- } \\
\text { change reduces uncertainties } \\
\text { with regard to vulnerability } \\
\text { assessments and increases the } \\
\text { avoidance of conflicts as well } \\
\text { as options for the identifica- } \\
\text { tion of co-benefits }[48,58]\end{array}$ & $\begin{array}{l}\text { Different data formats or analysis } \\
\text { software impeding easy transfer. } \\
\text { Lack of know-how regarding rele- } \\
\text { vant indicators and analysis meth- } \\
\text { ods represents another challenge } \\
\text { [44]; } \\
\text { Uncertainties regarding sectoral or } \\
\text { regional climate change impacts } \\
{[44,57]}\end{array}$ \\
\hline $\begin{array}{l}\text { Visions and } \\
\text { objectives }\end{array}$ & $\begin{array}{l}\text { Synchronised policy priori- } \\
\text { ties and joint resources for } \\
\text { thematic coordination and } \\
\text { prioritisation allow maximi- } \\
\text { sation of co-benefits or syn- } \\
\text { ergies [26] and avoidance of } \\
\text { lock-in effects }\end{array}$ & $\begin{array}{l}\text { For some sectors, climate change } \\
\text { adaptation is an "integral part of } \\
\text { their agenda", for others not [39]; } \\
\text { Differing interests or policy priori- } \\
\text { ties (e.g. prioritisation of economic } \\
\text { or specific sectoral objectives) } \\
\text { [32,47,57]; } \\
\text { Lack of knowledge on synergies } \\
\text { and trade-offs of climate proofing } \\
\text { measures across sectors [57] }\end{array}$ \\
\hline $\begin{array}{l}\text { Legal frameworks / } \\
\text { instruments }\end{array}$ & $\begin{array}{l}\text { Possibility of joint measures } \\
\text { within similar legal struc- } \\
\text { tures/exchange of expertise on } \\
\text { entry points for consideration } \\
\text { of climate change adaptation } \\
\text { [26] }\end{array}$ & $\begin{array}{c}\text { Non-harmonised or non-binding } \\
\text { planning frameworks or strategies } \\
\text { may impede integrative climate } \\
\text { proofing [57], as well as lacking or } \\
\text { diverging levels of detail within } \\
\text { specific planning instruments } \\
\text { [26], [59] }\end{array}$ \\
\hline Resources & $\begin{array}{l}\text { Shared cost burden, at least } \\
\text { for parts of the risk assess- } \\
\text { ment and adaptation process } \\
\text { [48]; } \\
\text { Possibility for efficient use of } \\
\text { human and financial re- } \\
\text { sources as well as space (in } \\
\text { the case of multi-functional } \\
\text { measures) [26] }\end{array}$ & $\begin{array}{l}\text { Uncertainties/ambiguities regard- } \\
\text { ing cost sharing [48] and limited } \\
\text { financial resources [59]; } \\
\text { Different internal structures, hier- } \\
\text { archies and responsibilities; } \\
\text { Asymmetries in political commit- } \\
\text { ment and cultures between differ- } \\
\text { ent partners may impede uptake } \\
\text { of administrative processes [57] }\end{array}$ \\
\hline
\end{tabular}

This case study area approaches vertical and horizontal cooperation for climate proofing despite very heterogenic planning systems and institutional capacities through cooperation in the PGO. This creates a novel opportunity to develop and discuss a new, integrative planning framework for climate proofing across sectors, planning areas and policy levels that integrates this knowledge on potential barriers in order to enable planners to adequately address them early in the process. 


\section{Presentation of the novel theoretical and methodological framework}

The literature covers a number of different frameworks regarding the planning and implementation of climate proofing measures $[14,51,60]$. What most of them have in common is a division into different phases, such as the preparation or implementation phase [see 61]. In this regard, the illustrated processes within these existing frameworks show many similarities. Despite the fact that some frameworks focus on specific aspects of the process (such as monitoring and evaluation [62] or finances [63]), many have a similar procedural design. They include processes of stakeholder analyses or engagement, the definition of common objectives, the specific planning and implementation of spatial planning measures, or, in some cases, the monitoring and evaluation of these measures in relation to the objectives defined initially.

The framework presented in this paper integrates established procedural steps identified in the analysis of existing frameworks and amends them to create a more holistic, precautionary approach for climate proofing in spatial planning. The primary objectives of the framework concept developed were its applicability to and coordination between different planning levels and instruments. The procedural steps presented fulfil two objectives: firstly, they help to identify the challenges resulting from climate change for different spatial planning levels (= vulnerability analysis). Secondly, they support the process of developing solutions that could be implemented by local and regional or, if relevant, cross-regional spatial planning institutions (= implementation and feedback). Figure 1 below represents the entire process and the links between the procedural steps.

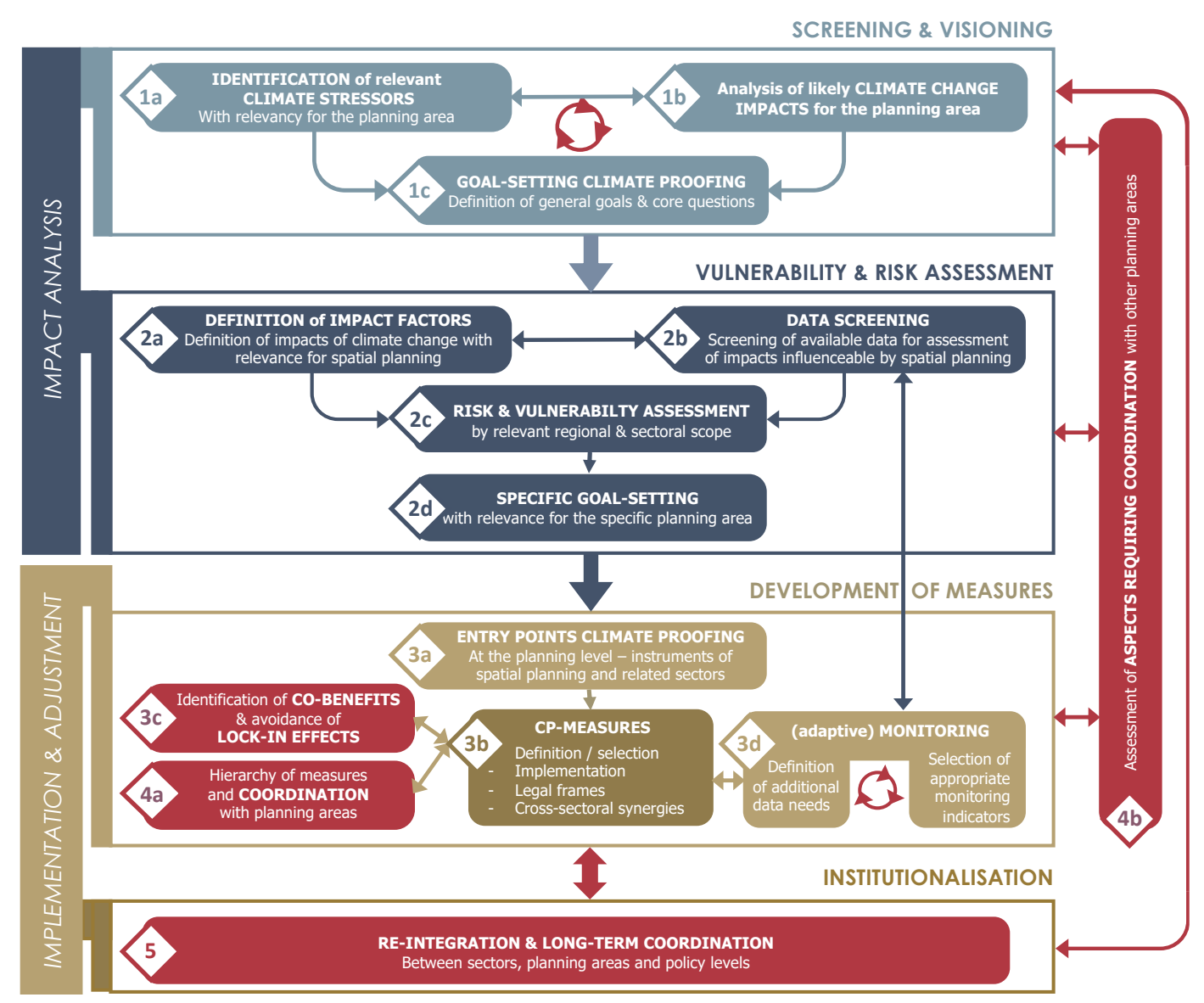

Figure 1: Framework concept for integrative "climate proofing" across planning areas and levels. Authors' illustration.

In order to estimate the vulnerability of specific planning areas to the consequences of climate change, it is necessary to define the meteorological parameters and indicators to which special attention should be paid (steps 1a and 1b). Possible indicators could be 
both current or expected change in frequency or intensity of the phenomenon under observation. Depending on the planning scale, existing adaptation strategies and policies already indicate the most spatially relevant challenges for climate proofing. According to the scale of planning or the meteorological phenomena to be included, the need for precise small-scale consideration can vary greatly.

The identification of specific climate proofing goals (step 1c) is done with respect to challenges in the specific planning area and should account for the following aspects:

- $\quad$ existing (overarching/superordinate) policies and goals.

- $\quad$ specific climatic, geographical and territorial conditions

- $\quad$ other active "drivers of change" (land use changes, population dynamics, economic aspects etc.)

- intermediary goals achieved hitherto regarding climate change adaptation or climate proofing.

- state of integration of relevant institutions for cross-sectoral coordination.

The initial definition of objectives and indicators by which to measure existing processes is a crucial preparatory step, especially with regard to the efficient use of resources and the feasibility of integrating climate proofing into spatial planning. It helps to identify the specific challenges of the planning area and, in doing so, allows a focus on existing efforts and resources for the selected indicators (steps $2 a$ and $2 b$ ).

For many possible climate change impacts, interrelationships with other land use changes are crucial. Therefore, the analysis of impact factors is an essential sub-step of this climate proofing framework, as also highlighted by Houghton \& Castillo-Salgado [17] and Rannow et al. [36] (step 2a). Changes in vegetation with regard to water retention capacity, for example, can mitigate or intensify the impacts of climate change both by themselves and in combination with other factors [64]. Another example for these interrelationships are changes in soil cover that affect the evaporation of water from the soil $[65,66]$. From a spatial planning perspective, particular focus may be placed on all those factors that can be actively influenced by planning decisions. Examples of this are the creation of fresh-air corridors by focusing on the appropriate layout of building structures, which in turn requires a forward-thinking approach to zoning determinations. Parameters such as the green space factor can be important in this context, depending on the specific planning level involved $[67,68]$. Especially with regard to the consideration of impact factors, it is indispensable to consider, at an early stage, which planning decisions are indicative for the subsequent planning levels (see step 3).

In contrast to the initial identification of targets (step 1), only a detailed analysis of projected impacts for the specific area under consideration (step 2) allows more precise subsequent determination of the level of local/regional vulnerability, taking into account both the appropriate climatic changes (step $2 b$ ) as well as the spatial impact factors (step $2 a)$. For step $2 \mathrm{~b}$ again climate change impact models from other planning units such as geology, water management or forestry can add important sources of information. Final assessment of the remaining vulnerability can be repeated at a later stage, after considering possible procedural and legal possibilities to implement "climate proofing" measures. In this regard, cross-sectoral coordination and cooperation can support the process of defining specific climate proofing targets for the planning area under consideration. Based on vulnerability analysis, specific goals can be defined with relevance for the specific planning area (step $2 \mathrm{~d})$.

While the first steps (as displayed in the vulnerability analysis) are part of many frameworks for climate change adaptation and climate proofing [see for example 35,6971]), the newly presented framework integrates the following new approaches, particularly throughout the development of measures to reduce negative impacts by climate change, to foster positive co-benefits for climate change mitigation and encourage learning loops also concerning vertical and horizontal cooperation. These aspects will be discussed in greater detail below: 


\subsection{Cross-level Coordination of Climate Proofing Options}

In order to be able to counter climate change impacts strategically and proactively through climate proofing, it is essential to reflect on which challenges can be countered at which planning level or from which level onwards.

An assessment across different levels is particularly relevant for the following four steps within spatial planning. Combined, they represent a large part of the overall planning process:

Firstly, cross-level tiering enhances the integration and coordination of goals across planning levels. In this way it attempts to contribute to the consistency of planning instruments between different sectors and planning levels and their respective goals. Integrating goals and information on climate change impacts from superior levels can in particular inform the definition of specific climate proofing objectives.

Secondly, the multi-scale perspective can facilitate the impact analysis process as well as the analysis of vulnerability (step 2). In this context, determination of the appropriate scale for identifying potential impacts (databases, indicators, tiering of the level of detail) (steps $2 a, 2 b, 2 c$ and $2 d$ ) is a crucial aspect which can be facilitated integrating higherplanning-level outcome documents as well as considering follow-up planning processes at a more detailed planning scale.

Thirdly, tiering allows exploitation of the full potential of hierarchy of measures, starting with identification of planning alternatives. Incremental examination of suitable measures for climate proofing is particularly important. Climate proofing measures in spatial planning have three main objectives:

- Securing of areas (risk or favourable areas or those with regulatory functions)

- Reduction of damage to buildings and infrastructure as well as risks to their users or inhabitants (technical and nature-based approaches)

- Securing the continuation of operational processes (especially with respect to critical infrastructure or transport-related accessibility).

Identification of the appropriate level for the implementation of climate proofing measures in connection with specific planning instruments (step 3a) allows precautionary planning at the appropriate level and concretisation according to legal entry points at each level [72]. This tiering or gradual assessment of the various available planning instruments ( $3 a$ and continuation in $3 b$ ) across different planning levels results in the possibility of developing climate proofing measures at an early stage and at an agreed level of detail. While, for example, the retention of fresh air corridors and production areas for cold air must already be ensured at a superordinate level, the small-scale and meso-climatic influence of different nature-related measures can only be specified in relation to local planning decisions [73]. In some cases, however, it may also be necessary to examine impacts across different planning areas.

Fourthly, cross-scale climate proofing can support the promotion of synergies between various adaptation goals and climate protection targets (steps 3b, 3c, 4a and 4b) and even more importantly prevent "lock-in effects" and $\mathrm{CO}_{2}$ sinks. Especially when identifying suitable measures across sectors and aiming to fostering synergies between them, a planning approach spanning planning areas may be essential. This may be the case, for example, in protecting against the impacts of heavy rainfall, where such an approach can yield potential for an early reduction of negative effects of climate change, implying cobenefits for other adaptation targets but also human health, tourism and recreation or biodiversity. This can be promoted both through planning at subordinate levels and through exchange or coordination at the immediate planning level within the individual steps of the framework. 


\subsection{Integration of Cross-Sectoral Perspectives}

In addition to spatial planning instruments, climate proofing can also benefit from planning in other sectors. Coordinated efforts can lead to synergies between suitable instruments. Cross-sectoral cooperation, as a need for effective climate change adaptation, has been described in several studies [57,74-76]. An exchange with other sectoral planning institutions may be beneficial or even necessary with regard to several parts of the planning process. This includes both the examination of challenges that may arise due to changing meteorological phenomena, as well as their impact on the planning area, and the definition of specific climate proofing targets and related uncertainties [44,57].

To sum up, an integrative assessment of challenges and opportunities for climate proofing can inform steps $1 \mathrm{c}, 2 \mathrm{~b}, \mathrm{c}$ and $\mathrm{d}, 3 \mathrm{a}, \mathrm{b}$ and $\mathrm{c}$, and 5 of the framework, in particular:

- When defining climate proofing objectives and identifying possible areas of conflict

- When aiming to obtain and coordinate spatially appropriate data

- $\quad$ For narrowing down the spatial "focus areas" to be considered for the particular climate proofing measures

- Throughout the analysis of planning alternatives

- In the process of identifying measures

- When monitoring the effects of climate change impacts on different spatial contexts and in the assessment of the achievement of objectives of the gradual measures implemented.

Climate service centres and/or scientific institutions can also provide relevant assistance, particularly in the case of strategic issues. They can support the interpretation of climate projections and may provide foresighted advice on which impact models or data sets are available to estimate the specific spatial impacts of climate change in the medium and/or long term.

Coordination with other sectoral spatial planning programmes can help to identify possible conflicts with regard to the predefined climate proofing objectives at an early stage. Such processes can help to utilise existing synergies based on a shared set of objectives between different planning sectors, which in turn allows broader positive outcomes of the measures to be achieved across different sectors [57].

\subsection{Re-integration and Long-Term Coordination Across Planning Levels and Planning Areas}

While often efforts for climate change adaptation are started dynamically, the longterm surveillance of their implementation as well as the effectiveness of the measures undertaken deserves institutionalisation. According to some researchers [32,45,77], institutionalised long-term cooperation in climate adaptation (and the related processes such as knowledge exchange) are at the heart of successful long-term climate proofing policies. However, attempts of institutionalisation have been complicated by a shift from centralized government to more inclusive and open governance structures [75].

As is evident from the previous sub-sections, both the definition and the achievement of objectives are influenced by the extent of coordination between different planning levels. Especially when surveying the implementation of measures, namely during monitoring, interaction between planning levels can be another influential factor. Feedback regarding the efficiency and effectiveness of measures at each level (step 5) can provide important guidance for future revisions. Furthermore, it can ensure that future targeting processes are aligned with newer, spatially resolved impact assessment models (step 3c).

Similarly, long-term coordination with adjacent planning areas also plays an important role in successful climate proofing. Combination with other land use changes and changes affecting spatial developments - in particular strategic processes in urban/suburban areas - can offer important incentives for transformation. These may also be relevant across administrative or planning boundaries. 
The framework presented offers a number of novel aspects that have not yet been part of common climate proofing frameworks. Referring to the categories used in Table 1, these novel aspects are displayed in Table 2.

Table 2. Novel aspects of the presented integrative climate proofing framework

\begin{tabular}{|c|c|c|}
\hline Categories & $\begin{array}{c}\text { Novel aspects of the presented } \\
\text { integrative framework }\end{array}$ & $\begin{array}{c}\text { Steps of the framework } \\
\text { process (see Figure 1) }\end{array}$ \\
\hline Data & $\begin{array}{l}\text { Integration of a recursive knowledge } \\
\text { exchange process across stakehold- } \\
\text { ers at different levels regarding rele- } \\
\text { vant impact factors and available da- } \\
\text { tabases }\end{array}$ & $\begin{array}{c}1 \mathrm{a}, 1 \mathrm{~b} \& \\
2 \mathrm{a}, 2 \mathrm{~b}, 2 \mathrm{c}\end{array}$ \\
\hline Visioning & $\begin{array}{l}\text { Integration of an inclusive and itera- } \\
\text { tive process of goal setting/visioning } \\
\text { with regard to both: general climate } \\
\text { proofing objectives and sectoral and } \\
\text { regional spatial-planning objectives; } \\
\text { Additional process to strengthen } \\
\text { knowledge and exchange among } \\
\text { stakeholders regarding the co-bene- } \\
\text { fits and lock-in effects of sectoral } \\
\text { measures }\end{array}$ & $1 c \& 2 d$ \\
\hline $\begin{array}{l}\text { Legal frameworks / } \\
\text { instruments }\end{array}$ & $\begin{array}{c}\text { Integration of an analysis and subse- } \\
\text { quent consideration of the current } \\
\text { state of harmonisation and overlaps } \\
\text { between different planning instru- } \\
\text { ments across planning areas and sec- } \\
\text { tors, serves as a basis for the defini- } \\
\text { tion of possible entry points for cli- } \\
\text { mate proofing within different plan- } \\
\text { ning institutions }\end{array}$ & $3 a$ \\
\hline $\begin{array}{l}\text { Institutionalisation } \\
\text { of } \mathrm{CP}\end{array}$ & $\begin{array}{l}\text { Integration of an institutionalised } \\
\text { and systematic process of coopera- } \\
\text { tion across different spatial planning } \\
\text { institutions across sectors, policy } \\
\text { levels and planning areas, taking } \\
\text { into account different co-benefits } \\
\text { and interaction effects across sectors }\end{array}$ & $\begin{array}{l}\text { Entire framework, } \\
\text { especially } 4 a, 4 b \text { \& } 5\end{array}$ \\
\hline
\end{tabular}

\section{Discussion and Outlook}

The framework presented shows a novel and integrative approach to climate proofing across sectors, planning areas and policy levels by combining academic insights on the inherent challenges of such complex planning processes with knowledge of various involved stakeholders.

A particular challenge addressed by the new framework concept is the proactive approach intended to foster synergies for different goals of climate proofing as well as climate change mitigation. "Nature-based solutions" can particularly contribute to these achievements. These measures can, for example, include the strategic and multifunctional implementation of green infrastructure [78]. The European Commission was also quick to emphasise the potential that this could represent. They also highlighted the benefits of combining climate change adaptation (e.g. in response to heatwaves, droughts and heavy 
rainfall) and climate change mitigation objectives by stating that this combined perspective could also bring other benefits, such as the conservation or restoration of biodiversity [79].

Another strength of the framework presented is its ability to counteract the occurrence of conflicting goals and interests. For spatial planning, strategic land management is an opportunity to consider potential synergies in order to ensure the best possible coordination of adaptation to heavy rainfall events and heat, for example. Likewise, objectives of nature conservation as well as agriculture (long-term land appraisal, irrigation needs, etc.) can be included in this context, at least indirectly. At the level of spatial research - both regional and local-an initial analysis of objectives would already be desirable. This would help to counteract possible conflict potentials and to include longer-term developments in land use planning and land use management.

The conceptual approach, despite being thoroughly discussed in workshops with the relevant actors from all three regions and tested for its applicability, faces possible limiting conditions in terms of practical implementation. As such, numerous studies have identified both drivers and barriers to climate change adaptation $[2,80,81]$, some of which have specifically been analysed in the context of multi-level, integrative approaches [32,82]. According to Swart et al. [2], not all characteristics are necessarily present in every process, but they may be interrelated and, as a result, present difficult challenges. Some of the barriers are particularly relevant for structures that extend planning areas, if they require different planning systems to interact with each other.

In the case of cross-sectoral cooperation projects including a range of public and private stakeholders from different sectors, the asymmetry in understanding of climate change projections or differing awareness of its severity was mentioned as a barrier in both a UK and a Zambia-based case study [82,83]. Widmer [32] also highlights the risk that the sectoral adaptation strategies mandated by planning authorities may be developed by existing staff members who lack specific climate knowledge, or that they may lack coherence in terms of content, structure or technical language. Another barrier their study identified is uncertainty related to the potential future economic benefits of investing in climate proofing measures [82], which may be a particularly relevant barrier when private stakeholders are involved, for whom such investments need to be met by tangible economic benefits. Linked to this was the threat of adaptation measures bringing about increasing long-term utilities for different sectoral departments (e.g. for maintaining green infrastructure), that are often avoided due to limited financial resources and project evaluations that disregard the non-monetary benefits of green spaces for example. In this regard, conflicts of interest between different planning institutions were mentioned as a threat to forward-thinking planning approaches, especially when priority is given to economic and development aims rather than environment- and health-focused aims within different sectoral planning agendas [32,82]. Given these conflicts of interest that may occur across sectors (especially those with a smaller overlap of sectoral goals with climate change considerations), several studies highlight the need for a leading or main coordinating department with a clear mandate for advancing the climate proofing of cities or regions [32,82]. Spatial planning as such has a core duty to consider conflicts of interest. The framework presented can help to counteract or encourage awareness of such problems by targeting the inclusion of different sectors early in the planning process and focusing on aligning their planning objectives and institutionalising joint planning processes.

In the case of climate proofing across administrative boundaries or planning areas, divergent administrative or legal structures or different departmental responsibilities can create problems. According to Widmer [32], this risk of differences in departmental structures and responsibilities also applies to collaboration across sectors. While some case studies exist that operate across planning areas, opportunities, challenges and corresponding solutions have not received much attention in the academic literature so far, 
creating a distinct research gap [see 26]. The framework presented, as well as its implementation in the case study of Eastern Austria, can help to close this gap by providing an overarching structure to facilitate the systematic analysis of processes.

For vertical cooperation across different policy levels, diverging proximity to the results of climate change, or differing degrees of being directly affected by it, represent a challenge to cooperation. While superordinate levels (i.e. national or federal state level) are needed to provide overarching guidelines, strategies and, in most cases, financial and other resources, actual implementation takes place at local level, where a certain degree of autonomy is required to adjust policy measures to specific local circumstances. Wamsler et al. [84] argue that the power struggles involved across different policy levels in Sweden result in a lack of coordination between their efforts. These misdirected efforts have great potential to negatively impact local adaptation capacities, which is why the authors suggest that countries should aim at linking policies across various policy scales rather than continuing with isolated efforts. Steurer et al. [85], in cases in the building sector in Switzerland and Austria, also highlight the risk of policies or strategies being "watered down" to the smallest common denominator by federal state/regional policymakers, partly in response to power struggles and lack of representation in the strategy development process.

To examine whether and to what extent the challenges mentioned above could impede implementation of the framework concept, empirical studies will be carried out in the planning area of Eastern Austria. This includes interviews with experts from spatial planning, but also with sectors relevant to spatial interaction with climate proofing, such as forestry and water management, in order to find out more about potential drivers and barriers to achieving an integrative climate proofing approach. They will be conducted and analysed in the next phase of the project and will allow adjustment of the framework presented to the specific challenges of the given planning context. The results are expected to foster processes of institutionalising climate proofing across different sectors as well as policy and planning levels.

Author Contributions: Conceptualization, A.J-P.; investigation, A.J-P., M.J., F.R; Authors; writingoriginal draft preparation, A.J-P., M.J., F.R.; writing, review and editing, A.J-P., M.J., F.R., R.W.; visualisation, F.R., M.J.; project administration, A.J-P., F.R.; funding acquisition, A.J-P., F.R. All authors have read and agreed to the published version of the manuscript.

Funding: This research was funded by Planungsgemeinschaft OST, whose purpose it is to coordinate and prepare spatial planning activities between the three federal Austrian states of Vienna, Lower Austria and Burgenland.

Acknowledgments: We particularly thank Beate Fellner, Alexandra Fischbacher and Ernst Tringl as well as all members of the project steering group.

Conflicts of Interest: The authors declare no conflict of interest. 


\section{References}

1. Goosen, H.; de Groot-Reichwein, M.A.M.; Masselink, L.; Koekoek, A.; Swart, R.; Bessembinder, J.; Witte, J.M.P.; Stuyt, L.; Blom-Zandstra, G.; Immerzeel, W. Climate Adaptation Services for the Netherlands: An operational approach to support spatial adaptation planning. Reg. Environ. Chang. 2014, 14, 1035-1048, doi:10.1007/s10113-013-0513-8.

2. Swart, R.; Sedee, A.G.J.; de Pater, F.; Goosen, H.; Pijnappels, M.; Vellinga, P. Climate-Proofing Spatial Planning and Water Management Projects: An Analysis of 100 Local and Regional Projects in the Netherlands. J. Environ. Policy Plan. 2014, 16, 5574, doi:10.1080/1523908X.2013.817947.

3. van den Brink, M.; Meijerink, S.; Termeer, C.; Gupta, J. Climate-proof planning for flood-prone areas: Assessing the adaptive capacity of planning institutions in the Netherlands. Reg. Environ. Chang. 2014, 14, 981-995, doi:10.1007/s10113-012-0401-7.

4. Labedens, S.; Scartezzini, J.; Mauree, D. Modeling the effects of future urban planning scenarios on the Urban Heat Island in a complex region. Urban Clim. 2018, 1-41.

5. Morabito, M.; Crisci, A.; Guerri, G.; Messeri, A.; Congedo, L.; Munafò, M. Surface urban heat islands in Italian metropolitan cities: Tree cover and impervious surface influences. Sci. Total Environ. 2021, 751, 142334, doi:10.1016/j.scitotenv.2020.142334.

6. Alcoforado, M.J.; Andrade, H.; Lopes, A.; Vasconcelos, J. Application of climatic guidelines to urban planning. The example of Lisbon (Portugal). Landsc. Urban Plan. 2009, 90, 56-65, doi:10.1016/j.landurbplan.2008.10.006.

7. Gruber, M.; Kanonier, A.; Pohn-Weidinger, S.; Schindelegger, A. Spatial Planning in Austria with References to Spatial Development and Regional Policy; ÖROK: Vienna, 2018; ISBN 9783950414639.

8. BMU Dem Klimawandel begegnen. Die deutsche Anpassungsstrategie; Berlin, 2009;

9. BMU Aktionsplan Anpassung der Deutschen Anpassungsstrategie an den Klimawandel vom Bundeskabinett am 31. August 2011 beschlossen. Available online: https://www.umweltbundesamt.de/themen/klima-energie/klimafolgenanpassung/anpassung-auf-bundesebene/aktionsplan-anpassung.

10. Altvater, S.; van de Sandt, K.; Marinova, N.; de Block, D.; Klostermann, J.; Swart, R.; Bouwma, I.; McCallum, S.; Dworak, T.; Osberghaus, D. Assessment of the most significant threats to the EU posed by the changing climate in the short, medium and long term - Task 1 report; Berlin, 2011;

11. Bollinger, L.A.; Bogmans, C.W.J.; Chappin, E.J.L.; Dijkema, G.P.J.; Huibregtse, J.N.; Maas, N.; Schenk, T.; Snelder, M.; van Thienen, P.; de Wit, S.; et al. Climate adaptation of interconnected infrastructures: A framework for supporting governance. Reg. Environ. Chang. 2014, 14, 919-931, doi:10.1007/s10113-013-0428-4.

12. Lomba-Fernández, C.; Hernantes, J.; Labaka, L. Guide for climate-resilient cities: An urban critical infrastructures approach. Sustainability 2019, 11, doi:10.3390/su11174727.

13. Hurlimann, A.C.; March, A.P. The role of spatial planning in adapting to climate change. Wiley Interdiscip. Rev. Clim. Chang. 2012, 3, 477-488, doi:10.1002/wcc.183.

14. Pütz, M.; Kruse, S.; Butterling, M. Bewertung der Klimawandel-Fitness der Raumplanung: Ein Leitfaden für PlanerInnen. 2011, 1-43.

15. de Groot-Reichwein, M.A.M.; Goosen, H.; van Steekelenburg, M.G.N. Climate proofing the Zuidplaspolder: A guiding model approach to climate adaptation. Reg. Environ. Chang. 2014, 14, 909-918, doi:10.1007/s10113-013-0509-4.

16. Birkmann, J.; Greiving, S.; Serdeczny, O.M. Das Assessment von Vulnerabilitäten, Risiken und Unsicherheiten. In Klimawandel in Deutschland: Entwicklung, Folgen, Risiken und Perspektiven; Brasseur, G.P., Jacob, D., Schuck-Zöller, S., Eds.; Springer Berlin Heidelberg: Berlin, Heidelberg, 2017; pp. 267-276 ISBN 978-3-662-50397-3.

17. Houghton, A.; Castillo-Salgado, C. Analysis of correlations between neighborhood-level vulnerability to climate change and protective green building design strategies: A spatial and ecological analysis. Build. Environ. 2020, 168, 106523, doi:10.1016/j.buildenv.2019.106523.

18. Kruse, S.; Pütz, M. Adaptive Capacities of Spatial Planning in the Context of Climate Change in the European Alps. Eur. Plan. Stud. 2014, 22, 2620-2638, doi:10.1080/09654313.2013.860516. 
19. Saunders, F.; Gilek, M.; Day, J.; Hassler, B.; McCann, J.; Smythe, T. Examining the role of integration in marine spatial planning: Towards an analytical framework to understand challenges in diverse settings. Ocean Coast. Manag. 2019, 169, 1-9, doi:10.1016/j.ocecoaman.2018.11.011.

20. UBA Klimaanpassung in der räumlichen Planung Starkregen, Hochwasser, Massenbewegungen, Hitze, Dürre; Dessau-Rößlau, 2016;

21. UBA Klimaanpassung im Raumordnungs-, Städtebau- und Umweltfachplanungsrecht sowie im Recht der kommunalen Daseinsvorsorge - Grundlagen, aktuelle Entwicklungen und Perpektiven; Dessau-Rößlau, 2018;

22. Hurlimann, A.; Wilson, E. Sustainable urban water management under a changing climate: The role of spatial planning. Water 2018, 10, 1-22, doi:10.3390/w10050546.

23. Birkmann, J.; Fleischhauer, M. Anpassungsstrategien der Raumentwicklung an den Klimawandel : " Climate Proofing “ Konturen eines neuen Instruments Adaptation strategies for spatial development to climate change :" Climate proofing " outline ofa new planning tool. Raumforsch. Raumordn. 2009, RuR Vol. 6, 114-127.

24. Pieterse, A.; Niekerk, W. Van; du Toit, J. Creating resilient settlements through climate change adaptation planning. Plan. Africa Conf. 20182018.

25. Bush, J.; Doyon, A. Building urban resilience with nature-based solutions: How can urban planning contribute? Cities 2019, 95, 102483, doi:10.1016/j.cities.2019.102483.

26. von Haaren, C.; Haller, C. Zukunftsfähiger Umgang mit Wasser im Raum; von Haaren, C., Haller, C., Eds.; VSB Verlagsservice Braunschweig GmbH: Hannover, 2011; ISBN 9783888380631.

27. Grafakos, S.; Pacteau, C.; Delgado, M.; Landauer, M.; Lucon, O.; Driscoll, P. Integrating Mitigation and Adaptation Opportunities and Challenges. In Climate Change and Cities: Second Assessment Report of the Urban Climate Change Research Network; Rosenzweig, C., Solecki, W., Romero-Lankao, P., Mehrotra, S., Dhakal, S., Ibrahim, S.A., Eds.; Cambridge University Press: New York, 2018; pp. 101-138 ISBN 978-1316603338.

28. Landauer, M.; Juhola, S.; Klein, J. The role of scale in integrating climate change adaptation and mitigation in cities. J. Environ. Plan. Manag. 2019, 62, 741-765, doi:10.1080/09640568.2018.1430022.

29. Probst, T.; Hohmann, R. Climate Adaptation Governance in Switzerland Final Country Report. 2018.

30. van Buuren, A.; van Buuren, A.; Driessen, P.P.J.; van Buuren, A.; Driessen, P.P.J.; van Rijswick, M.; van Buuren, A.; Driessen, P.P.J.; van Rijswick, M.; Rietveld, P.; et al. Towards Adaptive Spatial Planning for Climate Change: Balancing Between Robustness and Flexibility. J. Eur. Environ. Plan. Law 2013, 10, 29-53, doi:10.1163/18760104-01001003.

31. Bauer, A.; Feichtinger, J.; Steurer, R. The Governance of Climate Change Adaptation in 10 OECD Countries: Challenges and Approaches. J. Environ. Policy Plan. 2012, 14, 279-304, doi:10.1080/1523908X.2012.707406.

32. Widmer, A.M. Mainstreaming climate adaptation in Switzerland: How the national adaptation strategy is implemented differently across sectors. Environ. Sci. Policy 2018, 82, 71-78, doi:10.1016/j.envsci.2018.01.007.

33. GIZ Guiding Urban Concepts and Climate Change in Germany's Urban Planning Practice: A review of the recent academic discourse; Deutsche Gesellschaft für Internationale Zusammenarbeit GmbH (GIZ): Bonn, 2018;

34. Pietrapertosa, F.; Salvia, M.; De Gregorio Hurtado, S.; D’Alonzo, V.; Church, J.M.; Geneletti, D.; Musco, F.; Reckien, D. Urban climate change mitigation and adaptation planning: Are Italian cities ready? Cities 2019, 91, 93-105, doi:10.1016/j.cities.2018.11.009.

35. Floater, G.; Heeckt, C.; Ulterino, M.; Mackie, L.; Rode, P.; Bhardwaj, A.; Carvalho, M.; Gill, D.; Bailey, T.; Huxley, R.; et al. Co-benefits of urban climate action: A framework for cities. 2016, 86.

36. Rannow, S.; Loibl, W.; Greiving, S.; Gruehn, D.; Meyer, B.C. Potential impacts of climate change in Germany-Identifying regional priorities for adaptation activities in spatial planning. Landsc. Urban Plan. 2010, 98, 160-171, doi:10.1016/j.landurbplan.2010.08.017.

37. Araos, M.; Berrang-Ford, L.; Ford, J.D.; Austin, S.E.; Biesbroek, R.; Lesnikowski, A. Climate change adaptation planning in large cities: A systematic global assessment. Environ. Sci. Policy 2016, 66, 375-382, doi:10.1016/j.envsci.2016.06.009.

38. Widmer, A.M. The Governance of Climate Change Adaption in Switzerland Issues, Actors, and Processes at the National 
and Cantonal Level and in Land-use relevant Policies, ETH Zürich, 2014.

39. Widmer, A.M. Integrating Climate Change Adaptation Policy In Switzerland. 2016, 1-32.

40. Scheltema, M. Mainstreaming Urban Climate Adaptation Into Urban Planning and Design, Wageningen University, Netherlands, 2017.

41. Rechid, D.; Petersen, J.; Schoetter, R.; Jacob, D. Klimaprojektionen für die Metropolregion Hamburg; Hamburg, 2014; Vol. Band 1;

42. InKoKa Leitfaden zur Klimaanpassung: Ein Nachschlagewerk für Kommunen der Metropolregion Nordwest. 2016.

43. Vogt, V.; Atzl, S.; Klimopass, F. Entwicklung modellhafter Anpassungsstrategien der regionalen Straßeninfrastruktur in der Metropolregion Stuttgart an den Klimawandel. 2016.

44. Wachsmuth, J. Cross-sectoral integration in regional adaptation to climate change via participatory scenario development. Clim. Change 2015, 132, 387-400, doi:10.1007/s10584-014-1231-z.

45. Van Eerd, M.C.J.; Wiering, M.A.; Dieperink, C. Exploring the prospects for cross-border climate change adaptation between North Rhine-Westphalia and the Netherlands. Utr. Law Rev. 2014, 10, 91-106, doi:10.18352/ulr.271.

46. Vinke-de Kruijf, J.; Pahl-Wostl, C. A multi-level perspective on learning about climate change adaptation through international cooperation. Environ. Sci. Policy 2016, 66, 242-249, doi:10.1016/j.envsci.2016.07.004.

47. von Haaren, C.; Moss, T. Voraussetzungen für ein integriertes Management: Koordination und Kooperation der wasserrelevanten Akteure und Organisationen in Deutschland. In Zukunftsfähiger Umgang mit Wasser im Raum; von Haaren, C., Haller, C., Eds.; VSB Verlagsservice Braunschweig GmbH: Hannover, 2011; pp. 67-81.

48. UN Water Policy Brief Climate Change and Water. 2019, 1-8.

49. Persson, Å. Environmental policy integration: An introduction; Stockholm, 2004;

50. Ingram, J.; Hamilton, C. Planning for Climate Change: A Strategic, Values-Based Approach For Urban Planners; 2012; ISBN 9789211324006.

51. Calliari, E.; Staccione, A.; Mysiak, J. An assessment framework for climate-proof nature-based solutions. Sci. Total Environ. 2019, 656, 691-700, doi:10.1016/j.scitotenv.2018.11.341.

52. Aguiar, F.C.; Bentz, J.; Silva, J.M.N.; Fonseca, A.L.; Swart, R.; Santos, F.D.; Penha-Lopes, G. Adaptation to climate change at local level in Europe: An overview. Environ. Sci. Policy 2018, 86, 38-63, doi:10.1016/j.envsci.2018.04.010.

53. Harrison, P.A.; Dunford, R.W.; Holman, I.P.; Rounsevell, M.D.A. Climate change impact modelling needs to include crosssectoral interactions. Nat. Clim. Chang. 2016, 6, 885-890, doi:10.1038/nclimate3039.

54. IPCC Climate Change 2014: Synthesis Report.; Intergovernmental Panel on Climate Change (IPCC): Geneva, 2015; ISBN 9789291691432.

55. Rotterdam Climate Initiative Rotterdam: Climate change adaptation strategy; Rotterdam, 2013;

56. Kim, D.; Lim, U. Urban resilience in climate change adaptation: A conceptual framework. Sustainability 2016, 8, 1-17, doi:10.3390/su8040405.

57. Serrao-Neumann, S.; Crick, F.; Harman, B.; Sano, M.; Sahin, O.; van Staden, R.; Schuch, G.; Baum, S.; Low Choy, D. Improving cross-sectoral climate change adaptation for coastal settlements: Insights from South East Queensland, Australia. Reg. Environ. Chang. 2014, 14, 489-500, doi:10.1007/s10113-013-0442-6.

58. Van Eerd, M.C.J.; Wiering, M.A.; Meijerink, S. Integrated, transboundary climate-adaptation governance: exploring essential steps for the development of a cross-border and integrated climate adaptation strategy; Nijmegen, 2014; ISBN 9789492100115.

59. Ledda, A.; Di Cesare, E.A.; Satta, G.; Cocco, G.; Calia, G.; Arras, F.; Congiu, A.; Manca, E.; De Montis, A. Adaptation to climate change and regional planning: A scrutiny of sectoral instruments. Sustain. 2020, 12, doi:10.3390/su12093804.

60. Garstecki, T.; Brown, M.; Morrison, J.; Marvin, A.; Boenisch, N.; Martin, S.; Schumacher, P.; Boshoven, J. Conservation Standards Applied to Ecosystem-based Adaptation; Bishkek, 2020;

61. Neely, B.; Mccarthy, P.; Cross, M.; Enquist, C.; Garfin, G.; Gori, D.; Hayward, G.; Schulz, T. Climate Change Adaptation Workshop for Natural Resource Managers in the Gunnison Basin: Summary.; Southwest Climate Change Initiative: Gunnison, CO, US, 2010. 
62. GIZ; UNEP-WCMC; FEBA Guidebook for Monitoring and Evaluating Ecosystem-based Adaptation Interventions; Bonn, 2020;

63. World Bank Implementing Nature Based Flood Protection: Principles and implementation guidance.; Washington, DC, 2017;

64. Gan, G.; Liu, Y.; Sun, G. Understanding interactions among climate, water, and vegetation with the Budyko framework. Earth-Science Rev. 2021, 212, 103451.

65. Fini, A.; Frangi, P.; Mori, J.; Donzelli, D.; Ferrini, F. Nature based solutions to mitigate soil sealing in urban areas: Results from a 4-year study comparing permeable, porous, and impermeable pavements. Environ. Res. 2017, 156, 443-454, doi:10.1016/j.envres.2017.03.032.

66. Podhrázská, J.; Kučera, J.; Karásek, P.; Szturc, J.; Konečná, J. The Effect of Land Management on the Retention Capacity of Agricultural Land in the Conditions of Climate Change - Case Study. J. Ecol. Eng. 2020, 22, 258-266, doi:10.12911/22998993/130230.

67. Reinwald, F.; Ring, Z.; Kraus, F.; Kainz, A.; Tötzer, T.; Damyanovic, D. Green Resilient City - A framework to integrate the Green and Open Space Factor and climate simulations into everyday planning to support a green and climate-sensitive landscape and urban development. In Proceedings of the IOP Conference Series: Earth and Environmental Science; $2019 ;$ Vol. 323.

68. Vartholomaios, A.; Kalogirou, N.; Athanassiou, E.; Papadopoulou, M. The green space factor as a tool for regulating the urban microclimate in vegetation-deprived Greek cities. Proc. Int. Conf. "Changing Cities" Spat. Morphol. Form. socio-economic Dimens. 2013, doi:10.13140/2.1.1598.8484.

69. UN-Habitat Planning for Climate Change: A Strategic, Values-Based Approach for Urban Planners - Toolkit; 2014; ISBN 9789211324006.

70. UNISDR How To Make Cities More Resilient. A Handbook For Local Government Leaders; Geneva, 2012;

71. Chapman, E.; Nieuwenhuijs, A. User Guide: the Resin Decision Support Tools for Climate Change Adaption; Freiburg, 2018;

72. Nalau, J.; Preston, B.L.; Maloney, M.C. Is adaptation a local responsibility? Environ. Sci. Policy 2015, 48, 89-98, doi:10.1016/j.envsci.2014.12.011.

73. Damyanovic, D.; Reinwald, F.; Brandenburg, C.; Allex, B.; Gantner, B.; Morawetz, U.; Preiss, J. Pilot Action City of Vienna -UHI-STRAT Vienna. In Counteracting Urban Heat Island Effects in a Global Climate Change Scenario; Musco, F., Ed.; Springer International Publishing, 2016; pp. 257-280 ISBN 978-3-319-10425-6.

74. England, M.I.; Dougill, A.J.; Stringer, L.C.; Vincent, K.E.; Pardoe, J.; Kalaba, F.K.; Mkwambisi, D.D.; Namaganda, E.; Afionis, S. Climate change adaptation and cross-sectoral policy coherence in southern Africa. Reg. Environ. Chang. 2018, 18, 2059-2071, doi:10.1007/s10113-018-1283-0.

75. Biesbroek, G.R.; Swart, R.J.; Knaap, W.G.M. Van Der The mitigation - adaptation dichotomy and the role of spatial planning. Habitat Int. 2009, 33, 230-237, doi:10.1016/j.habitatint.2008.10.001.

76. Adger, W.N.; Arnell, N.W.; Tompkins, E.L. Successful adaptation to climate change across scales. Glob. Environ. Chang. 2005, 15, 77-86, doi:10.1016/j.gloenvcha.2004.12.005.

77. Vitale, C.; Meijerink, S.; Moccia, F.D.; Ache, P. Urban flood resilience, a discursive-institutional analysis of planning practices in the Metropolitan City of Milan. Land use policy 2020, 95, 104575, doi:10.1016/j.landusepol.2020.104575.

78. Gill, S.; Forest, T.M.; Ennos, R. Adapting Cities for Climate Change : The Role of the Green Infrastructure. Built Entvironment 2007, 33, 115-133, doi:10.2148/benv.33.1.115.

79. EC Guidance on Integrating Climate Change and Biodiversity into Environmental Impact Assessment; Brüssel, 2013;

80. Biesbroek, G.R.; Klostermann, J.E.M.; Termeer, C.J.A.M.; Kabat, P. On the nature of barriers to climate change adaptation. Reg. Environ. Chang. 2013, 13, 1119-1129, doi:10.1007/s10113-013-0421-y.

81. Simonet, G.; Leseur, A. Barriers and drivers to adaptation to climate change-a field study of ten French local authorities. Clim. Change 2019, 155, 621-637, doi:10.1007/s10584-019-02484-9.

82. Carter, J.G.; Cavan, G.; Connelly, A.; Guy, S.; Handley, J.; Kazmierczak, A. Climate change and the city: Building capacity for urban adaptation. Prog. Plann. 2015, 95, 1-66, doi:10.1016/j.progress.2013.08.001. 
83. Vincent, K.; Colenbrander, W. Developing and applying a five step process for mainstreaming climate change into local development plans: A case study from Zambia. Clim. Risk Manag. 2018, 21, 26-38, doi:10.1016/j.crm.2018.04.005.

84. Wamsler, C.; Johannessen, Å. Meeting at the crossroads? Developing national strategies for disaster risk reduction and resilience: Relevance, scope for, and challenges to, integration. Int. J. Disaster Risk Reduct. 2020, 45, doi:10.1016/j.ijdrr.2019.101452.

85. Steurer, R.; Clar, C.; Casado-Asensio, J. Climate change mitigation in Austria and Switzerland: The pitfalls of federalism in greening decentralized building policies. Nat. Resour. Forum 2020, 44, 89-108, doi:10.1111/1477-8947.12166. 